\title{
A floresta de cristal: notas sobre a ontologia dos espíritos amazônicos
}

\author{
Eduardo Viveiros de Castro
}

resumo $\mathrm{O}$ artigo propóe uma reflexão sobre a ontologia dos espíritos na Amazônia indígena. Uma narrativa de Davi Kopenawa (pensador e líder político yanomami) sobre os xapiripë (ancestrais animais ou espíritos xamânicos que interagem com os xamãs de seu povo) é tomada como inspiração central para uma discussão mais ampla sobre cosmologia e xamanismo na Amazônia. Nesta discussão, os conceitos amazônicos sobre os "espíritos" não apontam para uma classe ou gênero de seres, mas para uma síntese disjuntiva entre o humano e o não-humano. $\mathrm{O}$ tema da intensidade luminosa característica dos espíritos é interpretado em termos de uma ênfase não-representacional na visão como modelo da percepçáo e do conhecimento nas culturas ameríndias. Kopenawa afirma que os xamãs dos Yanomami sabem que sua floresta pertence ao xapiripë e é feita de seus "espelhos", isto é, cristais brilhantes. A floresta de cristal, portanto, não reflete ou reproduz imagens, mas ofusca, refulge e resplandece.

palavras-chave Yanomami. Ontologia. Espíritos. Cosmologia. Xamanismo. Luz.

Ces citoyens infinitésimaux de cités mistérieuses... Gabriel Tarde

\section{Introdução}

As reflexões aqui alinhavadas têm sua origem longínqua em meu trabalho junto aos Yawalapíti e Araweté, nas décadas de 1970 e 1980, onde, como todo etnógrafo, tive de confrontar diferentes noções indígenas sobre a agência dos não-humanos ${ }^{1}$. $\mathrm{O}$ evento que lhes serviu porém

1. Ver Viveiros de Castro ([1978] 2002a), para os Yawalapíti, e Viveiros de Castro 1992, para os Araweté. de catalisador imediato - de pretexto, se quiserem - foi a leitura, bem mais recente, de dois fragmentos de uma notável narrativa proveniente de outra cultura amazônica. Trata-se da exposição que Davi Kopenawa, pensador e líder político yanomami, faz ao antropólogo Bruce Albert sobre os xapiripë, "ancestrais animais" ou "espíritos xamânicos" que interagem com os xamãs de seu povo (Kopenawa 2000; Kopenawa $\&$ Albert 2003). Estes textos são parte de um diálogo em curso entre Kopenawa e Albert, no qual o primeiro apresenta aos Brancos, na pessoa de seu interlocutor-tradutor, uma concepção detalhada do mundo e da história, que é ao mesmo tempo uma reivindicação indignada e orgulhosa do direito dos Yanomami à existência ${ }^{2}$. A seguir transcrevo a versáo mais curta da narrativa, publicada em português em duas ocasiôes (Kopenawa 2000, 2004) ${ }^{3}$.

\section{Xapiripë}

Os espíritos xapiripë dançam para os xamãs desde o primeiro tempo e assim continuam até hoje. Eles parecem seres humanos mas são tão minúsculos quanto partículas de poeira cintilantes. Para poder vê-los deve-se inalar o pó da árvore yãkóanahi muitas e muitas vezes. Leva tanto tempo quanto para os brancos aprender o desenho de suas palavras. O pó do yãkóanahi é a comida dos espíritos. Quem não o "bebe"

2. O diálogo integral entre Kopenawa e Albert deve ser publicado muito brevemente. Ver, além dos dois fragmentos já citados, os diversos outros textos de Kopenawa e de Albert in Albert e Chandès (2003), bem como os importantes artigos de Albert (1988) e Albert (1993).

3. Transcrevo a versão publicada em 2004. 
dessa maneira fica com olhos de fantasma e não vê nada.

Os espíritos xapiripë dançam juntos sobre grandes espelhos que descem do céu. Nunca são cinzentos como os humanos. São sempre magníficos: o corpo pintado de urucum e percorrido de desenhos pretos, suas cabeças cobertas de plumas brancas de urubu rei, suas braçadeiras de miçangas repletas de plumas de papagaios, de cujubim e de arara vermelha, a cintura envolta em rabos de tucanos. Milhares deles chegam para dançar juntos, agitando folhas de palmeira novas, soltando gritos de alegria e cantando sem parar. Seus caminhos parecem teias de aranha brilhando como a luz do luar e seus ornamentos de plumas mexem lentamente ao ritmo de seus passos. Dá alegria de ver como são bonitos! Os espíritos são assim tão numerosos porque eles são as imagens dos animais da floresta. Todos na floresta têm uma imagem: quem anda no chão, quem anda nas árvores, quem tem asas, quem mora na água... São estas imagens que os xamãs chamam e fazem descer para virar espíritos xapiripë.

Estas imagens são o verdadeiro centro, o verdadeiro interior dos seres da floresta. As pessoas comuns não podem vê-los, só os xamãs. Mas não são imagens dos animais que conhecemos agora. São imagens dos pais destes animais, são imagens dos nossos antepassados. No primeiro tempo, quando a floresta ainda era jovem, nossos antepassados eram humanos com nomes de animais e acabaram virando caça. Sáo eles que flechamos e comemos hoje. Mas suas imagens não desapareceram e são elas que agora dançam para nós como espíritos xapiripë. Estes antepassados são verdadeiros antigos. Viraram caça há muito tempo mas seus fantasmas permanecem aqui. Têm nomes de animais mas são seres invisíveis que nunca morrem. A epidemia dos Brancos pode tentar queimá-los e devorá-los, mas eles nunca desaparecerão. Seus espelhos brotam sempre de novo.

Os Brancos desenham suas palavras porque seu pensamento é cheio de esquecimento. Nós guardamos as palavras dos nossos antepassados dentro de nós há muito tempo e continuamos passando-as para os nossos filhos. As crianças, que não sabem nada dos espíritos, escutam os cantos do xamás e depois querem que chegue a sua vez de ver os xapiripë. É assim que, apesar de muito antigas, as palavras dos xapiripë sempre voltam a ser novas. Sáo elas que aumentam nossos pensamentos. São elas que nos fazem ver e conhecer as coisas de longe, as coisas dos antigos. É o nosso estudo, o que nos ensina a sonhar. Deste modo, quem não bebe o sopro dos espíritos tem o pensamento curto e enfumaçado; quem não é olhado pelos xapiripë náo sonha, só dorme como um machado no chão.

Esta narrativa de Kopenawa - e aqui me refiro tanto ao texto acima como à versão mais desenvolvida de "Les ancêtres animaux" (Kopenawa \& Albert 2003) - parece-me um documento extraordinário. Antes de mais nada, ela impressiona pela riqueza e eloquência, qualidades que se devem à implementação deliberada, por parte dos dois autores, de uma estratégia discursiva de grande densidade poético-conceitual. Nesse sentido, estamos diante de um projeto de "invenção da cultura" (sensu Wagner 1981) que é ao mesmo tempo uma obra-prima de política "interétnica”. Se o xamanismo é essencialmente uma diplomacia cósmica dedicada à traduçáo entre pontos de vista ontologicamente heterogêneos ${ }^{4}$, então o discurso de Kopenawa não é apenas uma narrativa sobre certos conteúdos xamânicos - a saber, os espíritos que os xamãs fazem falar e agir; ele é uma forma xamânica em si mesma, um exemplo de xamanismo em ação, no qual um xamã tanto fala sobre os espíritos para os Brancos, como sobre os Brancos a partir dos espíritos, e ambas estas coisas através de um intermediário, ele mesmo um Branco que fala yanomami.

4. Viveiros de Castro (1998); Carneiro da Cunha (1998). 
Mas a narrativa é igualmente excepcional por sua exemplaridade cosmológica. Ela articula e desenvolve idéias que se encontram em estado mais ou menos difuso em diversas outras culturas indígenas da regiáo. Estamos aqui diante de uma versão forte, no sentido lévi-straussiano, da mitologia (explicita e implícita) dos espíritos amazônicos. É esta exemplaridade que interessa ao presente artigo, cujo propósito é chamar a atenção para algumas características relativamente comuns do modo de existência e manifestação dos espíritos na Amazônia indígena. Em particular, tomo o discurso de Kopenawa como exprimindo uma concepção pan-amazônica na qual as noçóes que traduzimos por "espírito" se referem a uma multiplicidade virtual intensiva.

\section{O plano de imanência xamânico}

Vários personagens salientes e contextos pregnantes da cosmologia yanomami se acham evocados no texto acima: os espíritos, os animais, os xamãs, os mortos, os brancos; o mito e o sonho, a droga e a festa, a caça e a floresta. Comecemos pelos xapiripë propriamente ditos. A palavra designa o utupë, imagem, princípio vital, interioridade verdadeira ou essência (Kopenawa \& Albert 2003: 72, n. 28) dos animais e outros seres da floresta, e ao mesmo tempo as imagens imortais de uma primeira humanidade arcaica, composta de Yanomami com nomes animais que se transformaram nos animais da atualidade.

Mas o termo xapiripë se refere também aos xamãs humanos, e a expressão "tornar-se xamã" é sinônima de "tornar-se espírito", xapiri-pru. Os xamás se concebem como de mesma natureza que os espíritos auxiliares que eles trazem à terra em seu transe alucinógeno. $\mathrm{O}$ conceito de xapiripë assinala portanto uma interferência complexa, uma distribuição cruzada da identidade e da diferença entre as dimensóes da "animalidade" (yaro peè) e da "humanidade" (yanomae thëpë). De um lado, os animais possuem uma essência invisível distinta de suas formas visíveis: os xapiripë são os "verdadeiros animais" - mas são humanóides. Isto é, os verdadeiros animais não se parecem demasiado com os animais que os xapiripe, literalmente, imaginam. De outro lado, os xamás se distinguem dos demais humanos por serem "espíritos", e mais, "pais" dos espíritos (que, por sua vez, são as imagens dos "pais dos animais"). O conceito de xapiripë, menos ou antes que designando uma classe de seres distintos, fala assim de uma regiáo ou momento de indiscernibilidade entre o humano e o não-humano (principal mas náo exclusivamente os "animais", noção que discutiremos mais adiante): ele fala de uma humanidade molecular de fundo, oculta por formas molares não-humanas, e fala dos múltiplos afetos não-humanos que devem ser captados pelos humanos por intermédio dos xamãs, pois é nisto que consiste o trabalho do sentido; literalmente, "são as palavras dos xapiripë que aumentam nossos pensamentos".

A reverberação entre as posiçóes de xamã e de espírito se verifica em diversas culturas amazônicas. No Alto Xingu, por exemplo, os grandes xamãs são chamados "espíritos" pelos leigos, enquanto eles próprios se referem a seus espíritos associados como "meus xamãs" (Viveiros de Castro 2002a: 80-1). Para os Ese Eja da Amazônia boliviana, "todos os eshawa [espíritos] são eyamikekwa [xamãs], ou melhor, os eyamikekwa têm os poderes dos eshaw' (Alexiades 1999: 226). Entre os Ikpeng do médio Xingu (Rodgers 2002), o termo pianom designa os xamãs, seus vários espíritos auxiliares e os pequenos dardos potencialmente auto-intoxicantes que estes espíritos introduzem no abdômen dos xamãs e que são o instrumento do xamanismo. Esta observação de Rodgers é importante por indicar que, se o conceito de espírito designa essencialmente uma população de afetos moleculares (ver adiante), uma multiplicidade intensiva, então o mesmo se aplica ao 
conceito de xamá: "o xamá é um ser múltiplo, uma micropopulação de agências xamânicas abrigada em um corpo" (op.cit., n.18). Longe de serem super-indivíduos, portanto, os xamãs - pelo menos os xamãs "horizontais" (HughJones 1996a) mais comuns na região - são seres super-divididos: federação de agentes sobrenaturais como nos Ikpeng, morto antecipado e vítima canibal potencial como nos Araweté (Viveiros de Castro 1992), corpo repetidamente perfurado como nos Ese Eja (Alexiades 1999: 221). Além disso, se o xamã é, efetivamente, "diferente", como dizem os Ikpeng (Rodgers op.cit.), resta que esta diferença entre os ele e os leigos é uma questão de grau, não de natureza. "Todo mundo que sonha tem um pouquinho de xamã” dizem os Kagwahiv (Kracke 1987), em cuja língua, como em muitas outras da Amazônia, as palavras que traduzimos por "xamã" não designam algo que se "é", mas algo que se "tem" - uma qualidade ou capacidade adjetiva e relacional mais que um atributo substantivo, qualidade que pode estar intensamente presente em muitas entidades não-humanas, que abunda, escusado dizer, nos "espíritos", e que pode mesmo constituir-se em potencial genérico do ser (Campbell 1989) 5 .

$\mathrm{O}$ "xamã” humano, assim, não é um tipo sacerdotal - uma espécie ou função -, mas alguém mais semelhante ao filósofo socrático - uma capacidade ou funcionamento. Pois se, como sustentava Sócrates, todo indivíduo capaz de raciocinar é filósofo, amigo potencial do conceito, então todo indivíduo capaz de sonhar é xamã, "amigo da imagem"6. Nas palavras de Kopenawa: "[Este é] o nosso estudo, o que nos ensina a sonhar. Deste modo, quem não bebe

5. O mesmo se diga de muitas das noções amazônicas de "alma", como mostrou Surrallés, entre outros, para o caso dos Candoshi (2003: 43-9).

6. Para o contraste entre o xamã e o sacerdote na Amazônia, ver Hugh-Jones (1996a) e Viveiros de Castro (2002b). o sopro dos espíritos tem o pensamento curto e enfumaçado; quem não é olhado pelos xapiripë não sonha, só dorme como um machado no chão.”. De passagem, observe-se que, se o estudo e a razão vigilante são a alucinação própria dos Brancos, a escrita é o seu xamanismo: "Para poder vê-los [os xapiripë] deve-se inalar o pó da árvore yãkóanahi muitas e muitas vezes. Leva tanto tempo quanto para os brancos aprender o desenho de suas palavras."7.

Como se sabe, boa parte da mitologia amazônica trata das causas e conseqüências da especiaçáo - a investidura em uma corporalidade característica - de diversos personagens ou actantes, todos eles concebidos como compartilhando originalmente de uma condição geral instável na qual aspectos humanos e não-humanos se achavam inextricavelmente emaranhados. Todos os seres que povoam a mitologia manifestam esse entrelaçamento ontológico, essa ambigüidade trans-específica que os faz, justamente, semelhantes aos xamãs (e aos espíritos):

Os animais que povoam a Terra de hoje não chegam nem perto, em termos de poder, dos animais originais, diferindo destes tanto quanto se diz que os humanos ordinários diferem dos xamãs [...] O Povo Primordial vivia exatamente como os xamãs vivem hoje, em um estado polimorfo... Depois de seu abandono da Terra, cada um dos Seres Primordiais se tornou o "Senhor" ou arache da espécie que engendrou (Guss 1989: 52, sobre os Ye'kuana of Venezuela).

Veja-se também S. Hugh-Jones (1979: 218) sobre os Barasana do Vaupés: "Os xamãs são o povo $\mathrm{He}$ por excelência"; como sabemos, o conceito de $H e$ designa o estado originário do cosmos, para onde os humanos retornam pelo veículo do ritual. Sobre os Akuriyó do Suriname,

7. Ver Gow (2001: 191-218) para uma análise brilhante da conexão escrita-xamanismo entre os Piro. 
F. Jara (1996: 92-4) observa que os xamãs - humanos ou animais, pois as espécies não-humanas também possuem xamãs - são os únicos seres que "mantêm as características primitivas anteriores à separação entre humanos e animais", em particular o poder de mutação inter-específica (e este poder é o verdadeiro poder).

Assim, a interferência sincrônica entre humanos e animais (mais geralmente, não-humanos) que se exprime nos conceitos de xamá e de espírito possui uma dimensão diacrônica fundamental, remetendo a um passado absoluto - passado que nunca foi presente e que portanto nunca passou, como o presente náo cessa de passar - em que as diferenças entre as espécies "ainda” não haviam sido atualizadas. $\mathrm{O}$ mito fala deste momento:

[- Gostaria de lhe fazer uma pergunta simples: o que é um mito?] - Não é uma pergunta simples, muito pelo contrário... Se você interrogar um índio americano, seriam muitas as chances de que a resposta fosse esta: uma história do tempo em que os homens e os animais ainda náo eram diferentes. Esta definiçáo me parece muito profunda. (Lévi-Strauss \& Eribon 1988: 193).

A definição é de fato profunda; aprofundemo-nos, então, nela. Não é descabido definir o discurso mítico como consistindo principalmente em um registro do processo de atualização do presente estado de coisas a partir de uma condição pré-cosmológica virtual dotada de perfeita transparência - um "caosmos" onde as dimensóes corporal e espiritual dos seres ainda não se ocultavam reciprocamente. Esse pré ou proto-cosmos, muito longe de exibir uma "indiferenciação" ou "identificação" originárias entre humanos e não-humanos, como se costuma caracterizá-lo, é percorrido por uma diferença infinita, ainda que (ou porque) interna a cada personagem ou agente, ao contrário das diferenças finitas e externas que constituem as espécies e as qualidades do mundo atual (Viveiros de Castro 2001). Donde o regime de "metamorfose", ou multiplicidade qualitativa, próprio do mito: a questão de saber se o jaguar mítico, por exemplo, é um bloco de afetos humanos em figura de jaguar ou um bloco de afetos felinos em figura de humano é rigorosamente indecidível, pois a metamorfose mítica é um acontecimento ou um devir (uma superposição intensiva de estados heterogêneos), não um processo de mudança (uma transposição extensiva de estados homogêneos). Mito não é história justamente porque metamorfose não é processo, "ainda" não é processo e "jamais foi" processo; a metamorfose é anterior e exterior ao processo do processo - ela é um devir.

A linha geral traçada pelo discurso mítico descreve, assim, a laminação instantânea dos fluxos pré-cosmológicos de indiscernibilidade ao ingressarem no processo cosmológico: doravante, as dimensóes humana e felina dos jaguares (e dos humanos) funcionaráo alternadamente como fundo e forma potenciais uma para a outra. A transparência originária ou complicação infinita onde tudo dá acesso a tudo se bifurca ou se explica, a partir de então, na invisibilidade (as almas humanas e os espíritos animais) e na opacidade (o corpo humano e as "roupas" somáticas animais) ${ }^{8}$ relativas que marcam a constituição de todos os seres mundanos - invisibilidade e opacidade relativas porque reversíveis, já que o fundo de virtualidade pré-cosmológica é indestrutível ou inesgotável. Como dizia Kopenawa (2003: 73,81 ) ao falar dos cidadãos infinitesimais da arqui-polis virtual, os xapiripë "nunca desaparecem [...] seus espelhos brotam sempre de novo [...] eles são potentes e imortais".

Disse logo acima que as diferenças pré-cosmológicas são infinitas e internas, em contraste com as diferenças finitas externas entre as espé-

8. Sobre os corpos animais como "roupas", ver Viveiros de Castro (1998). 
cies. Estou me referindo aqui ao fato de que o que define os agentes e pacientes dos sucessos míticos é sua capacidade intrínseca de ser outra coisa; neste sentido, cada ser mítico difere infinitamente de si mesmo, visto que é "posto" inicialmente pelo discurso mítico apenas para ser "substituído", isto é, transformado. É esta auto-diferença que define um espírito e que faz com que todos os seres míticos sejam espíritos. A suposta indiferenciação entre os sujeitos míticos é função de sua irredutibilidade radical a essências ou identidades fixas, sejam elas genéricas, específicas ou individuais (pense-se nos corpos destotalizados e "desorganizados" que vagueiam nos mitos).

Em suma: o mito propóe um regime ontológico comandado por uma diferença intensiva fluente absoluta, que incide sobre cada ponto de um contínuo heterogêneo, onde a transformação é anterior à forma, a relação é superior aos termos e o intervalo é interior ao ser ${ }^{9}$. Cada ser mítico, sendo pura virtualidade, "já era antes" o que "iria ser depois", e por isso não é, pois não permanece sendo, nada de atualmente determinado. Em contrapartida, as diferenças extensivas introduzidas pela especiaçáo (lato sensu) pós-mítica, ou seja, a célebre passagem do "contínuo" ao "discreto" que constitui o grande (mi)tema da filosofia estruturalista ${ }^{10}$, cristalizam blocos molares de identidade interna infinita - cada espécie é internamente homogênea, seus membros são idêntica e indiferentemente representativos da espécie enquanto tal -, blocos estes separados por intervalos externos, quantizáveis e mensuráveis, uma vez que as diferenças entre as espécies são sistemas finitos de correlação, proporção e

9. Compare-se isso com as "descontinuidades internas" de que fala M. Strathern em Partial connections (Strathern 1991: xxiii).

10. Para o desenvolvimento do tema no contexto da mitologia, ver Lévi-Strauss (1964: 58-63, 286-87, 325-26; 1971: 417-21, 605), bem como o excelente estudo de Schrempp (1992). permutaçáo de caracteres de mesma ordem e natureza. $\mathrm{O}$ contínuo heterogêneo do mundo pré-cosmológico dá assim lugar a um discreto homogêneo, nos termos do qual cada ser é só o que é, e só o é por não ser o que não é. Mas os espíritos são o testemunho de que nem todas as virtualidades foram atualizadas e que o turbulento fluxo mítico continua a rugir surdamente por debaixo das descontinuidades aparentes entre os tipos e espécies ${ }^{11}$.

\section{Humanos, animais, espíritos}

Tanto quanto podemos saber, todas as culturas amazônicas dispóem de conceitos que determinam seres análogos aos xapiripë. $\mathrm{Na}$ verdade, as palavras indígenas que traduzimos por "espírito" correspondem em geral a uma "categoria" fundamentalmente heteróclita e heterogênea, que admite uma quantidade de subdivisóes e contrastes internos, às vezes mais radicais que os que opóem os "espíritos" aos outros tipos de seres. Para ficarmos apenas com os Yanomami, os xapiripë ou "espíritos xamânicos" seriam somente uma espécie do gênero yai thëpë, que Albert traduz como "seres não-humanos invisíveis", noção que inclui também os espectros dos mortos, porepë, e os seres maléficos, në wâripë (Kopenawa \& Albert 2003: 68, n.2). E se os xapiripë são epitomizados pelas imagens dos humanos-animais primordiais, Kopenawa deixa claro que os xamãs também mobilizam, entre outras, as imagens $x a$ piripë do Trováo, do Raio, da Chuva, da Noite, dos Ancestrais Canibais, da Panela, do Algodáo, do Fogo e dos Brancos, bem como uma multidão de në wâripë (op.cit.: 79-81). Os xapiripë não são sempre belos e magníficos, pois podem ser terríveis e monstruosos; e eles compartilham da condição fantasmal dos mortos, pois são "formas espectrais”, isto é, imagens (op.cit.: 73). A noção

11. "E o sistema duro não interrompe o outro: o fluxo continua sob a linha, perpetuamente mutante..." (Deleuze \& Guattari 1980: 270). 
genérica de "náo-humanos invisíveis" pareceria unificar adequadamente essa diversidade interna da "categoria"; mas o problema é que esses nãohumanos possuem determinaçóes humanas fundamentais, seja no plano de sua forma corporal básica, seja no de suas capacidades intencionais e agentivas. Além disso, se tais não-humanos são normalmente invisíveis aos homens comuns, aos que estáo despertos e àqueles de "pensamento curto e enfumaçado", no contexto da alucinação xamânica eles são, ao contrário, supremamente visíveis, e visíveis em sua forma humana verdadeira (são "o verdadeiro centro" dos seres da floresta). Reciprocamente, há certas situações críticas em que uma pessoa encontra um ser que começa por se dar a ver como humano - em um sonho, em um encontro solitário na floresta - mas termina se revelando subitamente como não-humano; nestes casos, os não-humanos são aqueles supremamente capazes de assumir uma forma humana falsa perante os humanos verdadeiros. Em outras palavras, enquanto (normalmente) invisíveis, esses não-humanos "são" humanos; enquanto (anormalmente) visíveis, esses humanos "são" não-humanos ${ }^{12}$.

Por fim, notemos a natureza algo paradoxal de uma imagem que é ao mesmo tempo nãoicônica e não-visível. O que define os espíritos, em certo sentido, é indexarem os afetos característicos daquilo de que são a imagem sem, por isso, parecerem com aquilo de que são a imagem: são índices, não ícones. Ora, o que define uma "imagem” é sua visibilidade eminente: uma imagem é algo-para-ser-visto, é o correlativo objetivo necessário de um olhar, uma exterioridade que se póe como alvo da mirada intencional; mas os xapiripë são imagens interiores, "moldes internos", inacessíveis ao

12. Os espíritos são não-humanos, note-se, e não não-são humanos'. Em outras palavras, a extra-humanidade dos espíritos é um caso de "marca" ontológica (Valeri 2000: 28) em relaçáo ao estatuto não-marcado do humano como modo referencial do ser. exercício empírico da visão. Eles são o objeto, poder-se-ia dizer, de um exercício superior ou transcendental desta faculdade: imagens que seriam então como a condição daquilo de que são imagem; imagens ativas, índices que nos interpretam antes que os interpretemos; enigmáticas imagens que devem nos ver para que possamos vê-las - "quem náo é olhado pelos xapiripë não sonha, só dorme como um machado no chão" -; imagens através das quais vemos outras imagens

"só os xamãs podem ver [os espíritos], após ter bebido o pó de yãkoana, pois eles se tornam outros e passam a ver os espíritos igualmente com olhos de espírito" (Kopenawa \& Albert 2003: 77) ${ }^{13}$.

Tal não-iconicidade e não-visibilidade empíricas, em suma, parecem apontar para uma dimensão importante dos espíritos: eles são imagens não-representacionais, representantes que não são representaçóes.

"Todos os seres da floresta têm sua imagem $u t u$ $p \ddot{e}$... Em suas palavras, vocês diriam que eles são os 'representantes' [em português] dos animais" (Kopenawa \& Albert 2003: 72-3).

Albert assinala (loc.cit., n. 29) que o termo "representante" faz parte do vocabulário político habitual dos líderes indígenas. Pois bem; em Art \& Agency, ao introduzir a idéia dos símbolos anicônicos como "representantes”, Alfred Gell (1998: 98) usava o exemplo do diplomata: "[O] embaixador chinês em Londres... não se parece com a China; mas, em Londres, a China se parece com ele". O que se poderia parafrasear dizendo que os xapiripë náo se parecem com os animais, mas, no contexto mítico-xamânico, os animais se parecem com eles.

13. Ver loc.cit. n. 39, onde Albert observa que um xamã só pode ver um espírito através dos olhos de outro espírito, "com o qual se identificou" em seu transe. 
Nem tipos, nem representaçóes. O que estou sugerindo, enfim, é que os conceitos amazônicos de "espírito" não designam tanto uma classe ou gênero de seres quanto uma certa relação de vizinhança obscura entre o humano e o não-humano, uma comunicação secreta que não passa pela redundância, mas pela disparidade entre eles:

[N]ão há mais um sujeito que se eleva até à imagem, com ou sem sucesso. Dir-se-ia antes que uma zona de indistinção, de indiscernibilidade, de ambigüidade se estabelece entre dois termos, como se eles houvessem atingido o ponto que precede imediatamente sua diferenciação respectiva: não uma similitude, mas um deslizamento, um avizinhamento extremo, uma contigüidade absoluta; não uma filiação natural, mas uma aliança contra-natureza... (Deleuze 1993: 100).

Dir-se-ia que xapiripë é o nome da síntese disjuntiva que conecta-separa o atual e o virtual, o discreto e o contínuo, o comestível e o canibal, a presa e o predador. Neste sentido, efetivamente, os xapiripë "são outros"14. Um espírito, na Amazônia indígena, é menos assim uma coisa que uma imagem, menos uma espécie que uma experiência, menos um termo que uma relação, menos um objeto que um evento, menos uma figura representativa transcendente que um signo do fundo universal imanente - o fundo que vem à tona no xamanismo, no sonho e na alucinação, quando o humano e o náo-humano, o visível e o invisível trocam de lugar ${ }^{15}$. Menos um espíri-

14. "Vocês os chamam 'espíritos', mas eles são outros" (Kopenawa \& Albert 2003: 68).

15. "O enunciado de que alguma entidade não-humana é 'humana' é a marca de um discurso específico, o xamanismo", escreve Gow (2001: 67) a respeito dos Piro, enquanto Urban (1996: 222) observa que a arte xokleng de interpretação dos sonhos "consiste em identificar uma figura onírica como sendo um espírito disfarçado". Recorde-se, por fim, a incisiva e decisiva observação de Lienhardt sobre os espíritos dos Dinka, perfeitamente aplicável à Amazônia: “os to por oposição a um corpo imaterial que uma corporalidade dinâmica e intensiva, um objeto paradoxal que, como Alice, náo cessa de crescer e diminuir ao mesmo tempo: um espírito é menos que um corpo - os xapiripë são partículas de poeira, miniaturas de humanos dotados de micro-falos e a cujas mãos faltam dedos (Kopenawa $\&$ Albert 2003: 68) ${ }^{16}$ - e mais que um corpo - aparência magnífica, eventualmente terrificante, ornamentação corporal soberba, brilho, perfume, beleza, um caráter, em geral, excessivo em relação àquilo de que são a imagem (loc.cit. 73 n. 32; cf. também Viveiros de Castro 2002a). Em suma, uma transcorporalidade constitutiva, antes que uma negação da corporalidade: um espírito é algo que só é escasso de corpo na medida em que possui corpos demais, capaz como é de assumir diferentes formas somáticas. $\mathrm{O}$ intervalo entre dois corpos quaisquer, mais que um não-corpo ou corpo nenhum.

Mas se os conceitos amazônicos que traduzimos por "espírito" não designam, a rigor, entidades taxonômicas, e sim nomes de relaçóes, experiências, movimentos e eventos, entáo não é impossível que noçóes como as de "animal" e de "humano" tampouco constituam elementos de uma tipologia estática de gêneros do ser ou macro-formas categoriais de uma classificação "etnobiológica", sendo, ao contrário, coisa completamente diferente: como os espíritos, elas seriam dispositivos de imaginação. Sou levado a imaginar, assim (pois imaginar não é, justamente, classificar), um único domínio cósmico de transdutividade (Simondon 1995), um campo anímico basal dentro do

espíritos [ghosts] devem ser entendidos como reflexos de um tipo de experiência, não como uma classe de 'seres"' (1961: 153).

16. O imaginário dos espíritos amazônicos se compraz em construir espécies invisíveis corporalmente deformadas, com membros invertidos, articulações inexistentes, apêndices minúsculos ou gigantescos, interfaces sensoriais atrofiadas etc. Um bom exemplo são os abaisi dos Pirahã (Gonçalves 2001: 177-ss). 
qual os vivos, os mortos, os brancos, os animais e demais "seres da floresta", os personagens míticos antropomorfos e terionímicos e/ou vice-versa, as imagens xamânicas xapiripë e assim por diante seriam apenas diferentes vibraçóes ou modulaçóes intensivas e contínuas. Imagine-se então o "modo humano" como a freqüência fundamental deste campo anímico que se poderia designar globalmente de metahumano - já que a forma (interna e externa) humana é a referência aperceptiva deste domínio, toda entidade situada em posição de sujeito experimentando-se sub specie humanitatis ${ }^{17}$; imagine-se as espécies vivas e demais natural kinds (inclusive nossa própria espécie) como habitando o domínio de visibilidade deste campo; e imagine-se os "espíritos", ao contrário, como um modo ou grau de vibração do campo anímico que se acha tanto abaixo (minuscularidade granular, carência dimensional) como acima (anomalidade, excesso) dos limites de percepçáo do olho humano nu, o olho não investido pela droga alucinógena.

\section{Uma nota sobre a noçáo de "animal"}

Mas suponhamos, apenas para nos mantermos dentro da venerável tradiçáo taxonomizante de interpretação do pensamento selvagem, que se possam tratar os conceitos de espírito, de animal ou de humano como se foram classes ou categorias. As evidências etnográficas disponíveis sugerem que as cosmologias ameríndias não utilizam um conceito genérico de "animal (nãohumano)" que funcione como complemento lógico de um conceito de "humano". Os humanos são uma espécie entre muitas outras, e por vezes as diferenças internas à "humanidade" são equivalentes às diferenças interespecíficas: "Os Jívaro vêem a humanidade como uma coleção de sociedades naturais; a condição biológica comum

17. Ver Viveiros de Castro (1998), e mais adiante, sobre o 'perspectivismo' ameríndio. dos humanos interessa-lhes muito menos que as diferenças entre as formas de existência social" (Taylor 1993: 658; cf. também Surralès 2003: $111)^{18}$. Se assim é, então ao menos um significado básico da oposiçáo clássica entre Natureza e Cultura deve ser descartado quando consideramos a Amazônia e contextos similares: a natureza não é um domínio definido pela animalidade em contraste com a cultura como província da humanidade. $\mathrm{O}$ real problema com o uso da noção de natureza, aqui, reside menos em que ela se choca com o fato amazônico universal de que muitos animais também possuem cultura, mas sim na afirmação implícita de uma natureza enquanto domínio unificado por uma não-humanidade genérica (Gray 1996: 114).

São, com efeito, raras, se existentes, as línguas amazônicas que empregam um conceito coextensivo ao nosso "animal"19, embora não seja nada incomum ouvirmos termos mais ou menos correspondentes a um dos sentidos corriqueiros de "animal" em inglês (e menos comum em português): animais terrestres relativamente grandes, tipicamente mamíferos, por oposição a "peixe", "ave", "inseto" e outras formas de vida. Suspeito que a maioria das palavras indígenas que foram traduzidas por "animal" nas etnografias significam, na verdade, algo desse tipo. Três exemplos, entre muitos. (1) A palavra jê setentrional mbru or mru, usualmente traduzida em inglês por "animal", e às vezes empregada como uma sinédoque para "Natureza" (Seeger

18. Ver também Monod sobre os Piaroa: "Os Piaroa não se pensam enquanto homens, como fazemos; eles se pensam como uma espécie entre outras espécies. Há toda sorte de espécies de homens, como há toda sorte de espécies animais e vegetais" (1987: 138).

19. Estou ciente de que existem o que se chama de "categorias encobertas", i.e., formas conceituais não-lexicalizadas. $\mathrm{O}$ que estou afirmando, entretanto, é que na maioria dos casos amazônicos, senão em todos, não existe noção submersa que signifique "animal não-humano”. Naturalmente, esta afirmação pode ser desmentida a qualquer momento. 
1981), refere-se prototipicamente aos animais terrestres, possuindo o sentido pragmático e relacional de "presa”, “caça” ou "vítima”, é apenas nesta acepçáo pragmática que o termo pode ser aplicado aos peixes, aves etc. (Seeger com.pess.). (2) A palavra wari' (família txapakura) que se aplica aos "animais", karawa, possui o significado básico de "presa", e como tal pode ser aplicada aos inimigos humanos: o par contrastivo wari'karawa, que na maioria dos contextos pode ser traduzido como "humano/animal", possui o sentido logicamente englobante de "predador/presa" e mesmo de "agente/paciente". Os humanos (os Wari', i.e. os wari) podem ser os karawa de predadores animais, humanos ou espirituais, seres que, em sua função ou "momento" predatório são definidos como wari' (Vilaça 1992). (3) O terceiro caso é, justamente, o da língua yanomami, onde yaro, termo que compóe o conceito de yaroripee, que designa os "seres humanos com nomes de animais" que foram transformados em animais e as imagens animais xamânicas xapiripë, significa essencialmente "caça" (gibier; cf. Albert in Kopenawa \& Albert 2003: 73 n. 32), isto é, corpo-carne definido por sua destinaçáo alimentar:

Os Yanomami [i.e. humanos] queixadas viraram queixadas; os Yanomami veados viraram veados; os Yanomami cutias viraram cutias; os Yanomami araras viraram araras. Eles assumiram a forma dos queixadas, dos veados, das cutias e das araras que habitam a floresta hoje em dia. Sáo esses antepassados transformados que caçamos e comemos. Os animais que comemos são diferentes. Eles eram humanos e se transformaram em caça. Nós os vemos como animais, mas são Yanomami. São simplesmente habitantes da floresta. Somos semelhantes a eles, também somos caça. Nossa carne é idêntica, não fazemos senão trazer o nome de humanos. No começo do tempo, quando nossos antepassados ainda não tinham se transformados em outros, éramos todos humanos: as araras, os tapires, os queixadas, eram todos humanos. Depois, esses antepassados animais se transformaram em caça. Para eles, porém, somos sempre os mesmos, somos animais também; somos a caça que mora em casas, ao passo que eles são os habitantes da floresta. Mas nós, os que ficamos, nós os comemos, e eles nos acham aterrorizantes, pois temos fome de sua carne... (ibid: 75-6) ${ }^{20}$.

Se aquilo que se chamou "animal" significa sobretudo "presa", "caça”, ou simplesmente "carne", em alguns outros casos significará o exato oposto: espírito incomestível. Os Yawalapíti (aruaques do Alto Xingu) chamam de apapalutapa-mina uma variedade de animais, a maioria deles criaturas terrestres, tipicamente mamíferos - e todos eles, com uma exceção (os cebídeos), considerados impróprios para figurarem na dieta xinguana. A parte "animal" desta dieta se compóe principalmente de peixe,

20. Sobre os "Yanomami queixadas que viraram queixadas" etc., compare-se com o mito de origem dos animais dos Xokleng (Urban 1996: 181-2), que vivem mais de 3.000 quilômetros ao sul dos Yanomami: "Entrementes, alguns daqueles que haviam virado humanos [lit. 'que se tornaram aparentados a nós'] foram embora [como animais]. O queixada virou um queixada, e se foi. Então o queixada que havia sido humano [lit. 'nós os viventes'] se foi etc.”. No verso no 88 deste mito, a palavra traduzida em inglês por "animal" é a única palavra reconhecivelmente portuguesa utilizada pelo narrador: o genérico "bicho". À parte a fascinante tautologia do "queixada que virou queixada", idêntica ao mito yanomami, chamo a atenção para as duas perífrases que Urban traduz por "humano": "tornar-se parente" e "nós os viventes". A primeira parece sugerir que, se virar humano é virar parente, então virar animal é virar não-parente - virar afim potencial, talvez (Viveiros de Castro 2001)? A segunda sugere que virar animal é virar o contrário de nós-os-viventes - virar, pois, algo como "eles-os-mortos". Se "nós-os-viventes" é a expressão para "humano", como Urban traduz várias vezes a fórmula, então: (1) todos os viventes são humanos em certa medida; (2) todos os viventes nãohumanos são, na verdade, espécies de mortos (espectros, como diriam os Yanomami). 
e de algumas aves. A palavra apapalutapa-mina, que parece estar no mesmo nível de contraste que os termos para "peixe" e "ave", é provavelmente um composto de apapalutapa, "espírito", seguido de um modificador que conota algo como "membro não-prototípico da classe X" ou "exemplar inferior do tipo X", mas também "da mesma substância/natureza que X" (Viveiros de Castro 2002a). Nesse caso, os animais terrestres e todos os mamíferos seriam "como espíritos" ou "quase-espíritos". Isto é bastante similar a uma concepção barasana (Hugh-Jones 1996b) segundo a qual os animais de caça são chamados de "peixes velhos", onde o termo "velho" (ou "maduro") funciona como uma espécie de superlativo. Se os Barasana pensam os animais de caça como "super-peixes", o que implica que eles são um tipo particularmente perigoso de peixe, os Yawalapíti pensam os animais de caça como "subespíritos". E, enquanto os povos rionegrinos são capazes de reduzir eufemisticamente (e xamanisticamente) a caça que eles comem à condiçáo de "peixe", os povos xinguanos, que náo comem carne de caça, parecem considerar impossível desespiritualizar estes animais, e assim se vêem empiricamente "reduzidos" a comer peixe. Podemos assim estender o escopo do continuum amazônico de comestibilidade (no que concerne às fontes de proteína animal) proposto por Hugh-Jones, fazendo-o ir dos peixes aos espíritos, e não apenas aos seres humanos. Os rionegrinos principiam pelo pólo "peixe", definindo a caça como uma sub-classe deste; os xinguanos principiam pelo pólo oposto, fazendo dos animais "de caça” uma subclasse de "espírito". Isso sugere que os espíritos são os seres supremamente incomestíveis - o que faz deles os supremos canibais do universo, e/ou, como é o caso os xapiripë da narrativa yanoma$\mathrm{mi}$, seres que vivem de anti-alimentos (a droga alucinógena yãkoana e o tabaco) e de "anti-excrementos" (alimentos doces, perfumados e impolutos que náo apodrecem dentro do corpo como a carne que comemos) (Kopenawa \& Albert 2003: 81, 84-5) $)^{21}$.

\section{Perspectivas}

Minha referência, mais acima, aos espíritos e animais como mergulhados em um campo anímico universal de que eles seriam os modos respectivamente invisíveis e visíveis de "vibração" não é a uma analogia visualista inteiramente arbitrária. A narrativa de Kopenawa fala, com efeito, dos "olhos de fantasma" dos não-xamãs. A alusão aqui é aos espectros dos mortos (porepë) e à inversão perspectiva entre as diferentes modulaçóes ontológicas do meta-humano - um tema crucial nas ontologias ameríndias (Viveiros de Castro 1998):

Quando o sol sobe no céu, os xapiripë dormem. Quando ele começa a descer, à tarde, para eles a aurora começa a surgir. Eles despertam todos, inumeráveis, na floresta. Nossa noite é para eles o dia. Enquanto dormimos, eles se divertem, dançam. E quando falam de nós, chamam-nos espectros. Aparecemos aos seus olhos como fantasmas, pois somos semelhantes a estes. Eles [os xapiripë] nos falam assim: "vocês são estrangeiros e assombraçóes, porque vocês morrem" (Kopenawa \& Albert 2003: 68).

Os espíritos vêem os não-xamãs sob a forma de espectros; do mesmo modo, a invisibilidade usual dos espíritos aos olhos dos humanos (não-xamãs) é expressa dizendo-se que estes últimos possuem "olhos de espectro". (Os Brancos, portanto, são todos espectros, e sempre espectros, uma vez que são supremamente incapazes de ver os espíritos.) Reciprocamente, é ao "morrer" sob o efeito da droga alucinógena yãkoana que os xamãs são capazes não apenas

21. Na verdade, os xapiripë se alimentam de seus peidos perfumados, que inalam de suas mãos postas em concha (loc.cit.). 
de ver os espíritos, mas de ver como os espíritos (op.cit.: 68, n.2, 84, n.64): ver, justamente, os humanos como espectros. Neste sentido, pelo menos, os xamás dos Yanomami são mortos, isto é, espectros, ou pelo menos são humanos que deixaram de ser completamente humanos $^{22}$. Por sua vez, os xapiripë compartilham da condição espectral com os mortos, do "ponto de vista" dos humanos comuns: eles são "fantasmas" ${ }^{23}$. Quanto aos animais, já vimos como eles nos vêem - como seus semelhantes, mas estranhos: animais ao mesmo tempo domésti$\cos$ ("habitantes de casas") e canibais ${ }^{24}$.

Em suma, os espectros dos mortos estão, na ordem da ontogênese, como os animais na ordem da filogênese: ambos são humanos passados, e portanto ambos são imagens atuais de humanos. Não é de surpreender assim que, enquanto imagens definidas por sua disjunção relativamente a um corpo humano, os mortos sejam atraídos pelos corpos animais; é por isso que morrer é transformar-se em animal, como acontece tão freqüentemente na Amazônia. Com efeito, se as almas dos animais são concebidas como tendo uma forma corporal humana, é bastante lógico que as almas dos humanos sejam concebidas como tendo um corpo animal póstumo, ou como entrando em um corpo animal, de modo a poder ser eventualmente morta e comida pelos viventes ${ }^{25}$.

22. Os Ikpeng, aliás, concebem-nos como "ex-pessoas", tenpano-pin (Rodgers 2002: 112).

23. "A expressão nё porepë, “em forma espectral” ... é freqüentemente proposta como sinônimo de utupë, a imagem-essência xamânica (Albert in Kopenawa \& Albert 2003: 73 n.33).

24. Albert (in Kopenawa \& Albert 2003: 68 n.2) sintetiza: "Os espíritos vêem os humanos sob a forma de assombraçóes [revenants]; os animais os percebem como semelhantes que se tornaram 'moradores de casas'... os seres maléficos os consideram como caça... e as assombraçôes os vêem como parentes abandonados".

25. Para as relações entre mortos e animais, ver alguns exemplos em: Schwartzmann 1988: 268 (Panara);
Tudo o que precede pode ser tomado como significando que, na Amazônia, "a dialética primária é aquela entre o ver e o comer", como formulou elegantemente G. Mentore (1993: 29) a propósito dos Waiwai. O cru e o cozido estruturalista não é radicalmente outra coisa que o visível e o invisível fenomenológico: Merleau-Ponty encontra, mais uma vez, Lévi-Strauss. As culturas ameríndias, de fato, manifestam um forte viés visual todo próprio, que pouco tem a ver com o táo vilipendiado visualismo ou oculocentrismo ocidental (ver Smith 1998, Ingold 2000). A visão é freqüentemente tomada como modelo da percepção e do conhecimento (Mentore 1993; Alexiades 1999: 239; Alexiades 2000; Surralès 2003); o xamanismo está carregado de conceitos visuais (Chaumeil 1983; Gallois 1984-85; Roe 1990; Townsley 1993; Kelly 2003: 236); em grande parte da Amazônia - os Yanomami são um excelente exemplo - drogas alucinógenas são um instrumento básico da tecnologia xamânica, sendo usadas como próteses visuais. De maneira mais geral, a distinçáo entre o visível e o invisível parece desempenhar um papel maior na região: "a distinção fundamental na ontologia cashinaua [é aquela] entre visibilidade e invisibilidade" (Lagrou 1998: 52; cf. também Kensinger 1995: 207; Gray 1996: 115, 177). Podemos também recordar a forte ênfase na decoração e na exibição de superfícies corporais e artefactuais, açóes estas concebidas como processos epistêmica e ontologicamente eficazes (ver Gow 1999, 2001 para análises em profundidade da visáo em uma cultura amazônica) ${ }^{26}$.

Vilaça 1992: 247-55 (Wari'); Turner 1995: 152 (Kayapó); Pollock 1985: 95 (Kulina); Gray 1996: 157-78, 178 (Arakmbut); Gow 2001: ch. 5 (Piro); Alexiades 1999: 134, 178 (Ese Eja); Weiss 1972: 169 (Campa); Clastres 1968 (Aché).

26. Entre muitos exemplos das implicaçóes entre o exercício da visão e as determinações alimentares, des- 


\section{O brilho dos cristais}

Minha caracterização da ontologia dos espíritos amazônicos em registro visual não se deve apenas à presença, no discurso de Kopenawa, do tema do perspectivismo enquanto processo de comutação discreta de pontos de vista entre as diferentes formas de agência que povoam o cosmos. Outra coisa parece-me muito mais importante neste discurso: o funcionamento de uma poderosa imagística intensiva da cintilação e do reflexo luminoso, por um lado, e da divisibilidade-multiplicação indefinida dos espíritos, por outro.

Primeiro, a luz. A narrativa de Kopenawa está literalmente constelada de referências à luminosidade, ao brilho, às estrelas e aos espelhos. Na versão que reproduzi no começo deste artigo, vemos os espíritos como "poeiras luminosas", vemos seus caminhos, "tão finos como teias de aranha... vemo-los brilhar, inumeráveis, de uma claridade lunar"; vemos os “imensos espelhos” em que eles viajam, veículos resplendentes que estão "sempre a brotar de novo". Na versão expandida da narrativa (Kopenawa \& Albert 2003), a féerie luminosa prolifera: ao longo de doze páginas, pratica-

taquem-se os seguintes: (1) O comentário de Peter Gow: "Quando perguntava aos Piro por que eles gostavam de tomar ayahuasca, eles davam duas respostas características. Primeiro, diziam que era bom vomitar, e que a ayahuasca limpava o corpo dos resíduos da carne de caça que eles haviam comido. Tais resíduos se acumulam com o tempo, causando um mal-estar e um cansaço generalizados, que terminavam causando um desejo do morrer. [Compare-se aqui: 'A carne da caça que comemos se decompóe dentro de nós. Em troca, o corpo dos xapiripë não contém nenhuma carne corrompida...' - Kopenawa \& Albert 2003: 85] Em seguida, as pessoas me diziam que era bom tomar ayahuasca por que ela fazia você ver; como disse um homem, 'você pode ver tudo, tudo"' (2001: 139). (2) A observação de Miguel Alexiades (1999: 194) segundo a qual os edosikiana, espíritos dos Ese Eja, são invisíveis a todos os humanos exceto o xamã, pois quem vê um edosikiana é devorado por ele. mente uma em cada duas frases traz os xapiripë "brilhando como estrelas", emitindo "uma luminosidade deslumbrante", "uma luz resplandecente", "uma claridade cegante”... Quando descem à terra, eles acenam com "folhas novas de palmeira desfiadas que brilham com um amarelo intenso". Seus dentes "são imaculados e brilhantes como o vidro; quando [os dentes] são demasiado pequenos, ou se faltam, [os $x a-$ piripë] os substituem por fragmentos de espelhos". O solo sobre o qual eles dançam "parece vidro, e brilha com uma luz rutilante”...

A qualidade primordial da percepção dos espíritos é, assim, sua intensidade luminosa. Essa é uma experiência freqüentemente descrita na Amazônia. Os Mä̈, espíritos celestes canibais dos Araweté, são caracterizados por meio de um abundante vocabulário da cintilação ígnea e do relampejar ofuscante, e sua decoração corporal se destaca pela cor e luminosidade intensas (Viveiros de Castro 1992). Os espíritos dos Hoti, os "Senhores do Fora, ou da Floresta", "são detectados no mundo da vigília por meio do trovão e do relâmpago, que são seus gritos e o rebrilho de suas lanças; às vezes eles são vistos, ou ouvidos, como jaguares. São percebidos nos sonhos como seres antropomorfos luminosos, pintados de urucum vermelho-brilhante" (Storrie 2003: 417). Como os xapiripë yanomami, portanto, os Maï araweté e os Senhores hoti "nunca são cinzentos como os humanos; [eles têm o corpo] untado de urucum rubro e percorrido de desenhos ondulados, de riscos e manchas de um negro reluzente...”.

Sem dúvida, boa parte dessa fenomenologia da luz intensa pode estar associada aos efeitos bioquímicos das drogas. Assim os Piro, por exemplo, descrevem a experiência de ingestáo de toé (Brugmansia spp.): "De repente tudo se acende, como se o sol tivesse nascido..." (Gow 2001: 136). Seu etnógrafo observa que "a metaforização da experiência alucinatória do toé 
como 'luz do dia' [daylight] é corriqueira... outros informantes enfatizaram a 'vermelhidão’ da experiência, ‘justo como o mundo ao alvorecer', ou 'durante o pôr do sol'” (loc.cit.). Mas outras drogas menos violentamente alucinógenas que o toé dos Piro e o yaakoana dos Yanomami, como o tabaco, e outras técnicas de manipulação sensorial, como o semicegamento deliberado por meio de máscaras (Rodgers 2002), a aplicação de gotas oculares, a imersão, a privação de sono, etc, podem estar envolvidas nesses processos de desterritorialização do olhar. E de qualquer forma, a experiência perceptiva da intensidade luminosa é buscada pelo xamá, não meramente sofrida como se um efeito colateral de drogas tomadas em vista de outras sensaçóes, o que sugere fortemente que essa experiência possui um valor conceitual em si mesma. Naturalmente, não é preciso ser xamã para "perceber" a relação entre conhecimento e iluminação, tema provavelmente universal. Minha impressão, entretanto, é que não se trata, no caso amazônico, de uma concepção da luz como distribuindo relaçóes de visibilidade-cognoscibilidade em um espaço extensivo (estou pensando aqui em algumas passagens de Les mots et les choses), mas da luz como intensidade pura, coração intensivo da realidade que estabelece a distância inextensa entre os seres - sua maior ou menor capacidade mútua de devir. A conexão disto com a idéia da invisibilidade dos espíritos me parece crucial: aquilo que é normalmente invisível é também o que é anormalmente luminoso. A luminosidade intensa dos espíritos indica o caráter super-visível destes seres, que são "invisíveis" ao olho desarmado pela mesma razáo que a luz o é - por ser a condição do visível.

Entre os Araweté, como provavelmente para outros povos da Amazônia, a luminosidade e o brilho estão associados a uma outra qualidade visual, a transparência ou diafaneidade. Ikuyaho, "translucidez" ou "transparência"
- mas também "fora de casa", "ao ar livre", "no exterior” (cf. os Senhores do Fora dos Hoti) -, é um estado que os xamás procuram atingir mediante a ingestáo massiva de tabaco (que pode produzir um período de choque cataléptico). Estado associado à qualidade de "leveza" (wewe), a translucidez é produzida por uma separação entre a alma e o corpo (por uma exteriorização do ser, então), que retira deste último seu "peso" (ipohi) ou sua opacidade ("a opacidade ordinária do corpo humano" - Gow 2001: 135), permitindo assim ao xamã ver através do corpo de seus pacientes, e, mais geralmente, enxergar o lado invisível do mundo (Viveiros de Castro 1992: 131, 219-20; cf. também a "luminescência xamanística" do payé tukano em Reichel-Dolmatoff 1975: 77, 109). Foi este conceito de ikuyaho que me levou à imagem da transparência pré-cosmológica originária, desenvolvida algumas páginas mais acima. A outra fonte desta imagem foi uma maravilhosa passagem proto-leibniziana de Plotino sobre o mundo inteligível, que me pareceu possuir mais de um ponto de contato com a narrativa de Kopenawa - um ponto extremo que a toca, digamos assim:

pois tudo é transparente, nada é obscuro, nada impenetrável; todo ser é lúcido a todo outro ser, em profundidade e largura; e a luz atravessa a luz. E cada ser contém todos os seres dentro de si, e ao mesmo tempo vê todos os seres em cada outro ser, de tal forma que em toda parte há tudo, e todos sáo tudo e cada um são todos, e infinita é a glória. Cada ser é grande; o pequeno é imenso; o sol, lá, é todas as estrelas; e cada estrela é todas as estrelas, e o sol. E embora certos modos do ser sejam dominantes em cada ser, todos estáo espelhados em cada um. (Enéadas, $\mathrm{V}, 8,4)$.

Seria preciso apenas trocar a metafísica molar e solar do Um neoplatônico pela metafísica 
da multiplicidade lunar, estelar e molecular indígena ${ }^{27}$.

Os "espelhos" em que abunda a narrativa de Kopenawa são precisamente o instrumento de passagem entre as experiências da intensidade luminosa e da inumerabilidade dos espíritos, isto é, à sua infinitude quantitativa. Como se foram imagens da imagem, os espelhos se multiplicam na narrativa, ao mesmo tempo signo da presença e meio de deslocamento dos xapiripë:

Os xapiripë descem também até nós sobre espelhos, que eles mantêm acima do solo, sem jamais tocar na terra. Estes espelhos provêm de sua morada no peito do céu. Assim, na habitação dos espíritos de um xamã, esses espelhos estão postos, encostados, pendurados, empilhados, arrumados lado a lado. Quando a casa é vasta, os espelhos são grandes, e, quando o número de espíritos aumenta, seus espelhos se empilham aos poucos uns por cima dos outros. Mas os xapiripë não se misturam entre si. Os espelhos dos mesmos espíritos se sucedem uns após os outros, nos mesmos esteios da casa. Sucedem-se assim os espelhos dos espíritos guerreiros, dos espíritos aves de rapina e dos espíritos cigarras; os espelhos dos espíritos trovóes, e dos espíritos relâmpagos, dos espíritos tempestades. Há tantos espelhos quanto espíritos; eles são verdadeiramente inumeráveis, empilhados a se perder de vista. No sopé da Montanha do Vento, onde está minha casa, há grandes espelhos [dos xapiripë] na floresta. Nós, nós não fazemos mais que viver no meio de seus espelhos... [...] [Os xamâs dos Yanomami] sabem que nossa floresta pertence aos xapiripë, e que ela é feita de seus espelhos [ibid: 78-9].

27. O leitor terá compreendido que o advérbio "apenas" é aqui uma litotes. Para avaliarmos o papel decisivo da Lua e das estrelas na cosmologia yanomami e, mais geralmente, na mitologia ameríndia, é preciso voltar a certas páginas luminosas (se me permitem) de LéviStrauss em L'Origine des manières de table, tema que conto desenvolver em outra ocasião.
Os espelhos e os cristais desempenham um papel importante em todo o vocabulário amazônico (sobretudo norte-amazônico) do xamanismo: pense-se nos cristais xamânicos dos Tukano e de vários povos Caribe da Guiana, nas "caixas de cristal dos deuses" dos Piaroa, nos espelhos warua que recobrem o xamá Wayápi; pense-se, mais geralmente, na simetria dual especular interna característica da arte e da estética alucinatória da regiáo (ver Roe 1982, 1990; Overing 1985; Gallois 1996) ${ }^{28}$.

Mas os espelhos dos espíritos - que espécie de imagem refletiriam eles? É interessante notar que virtualmente todos os exemplos dados nesta seção - com a possível exceção das observaçóes de P. Roe sobre a simetria "especular" da arte amazônica, as quais exigem uma discussão impossível de se fazer aqui - não enfatizam a propriedade icônica que têm os espelhos de reproduzir imagens. $\mathrm{O}$ que os exemplos sublinham é, antes, a propriedade que têm os espelhos de ofuscar, refulgir e resplandecer. Os espelhos sobrenaturais amazônicos não são dispositivos representacionais extensivos, espelhos refletores ou "reflexionantes", mas cristais intensivos, instrumentos multiplicadores de uma experiência luminosa pura, fragmentos relampejantes. $\mathrm{Na}$ verdade, a palavra yanomami que Bruce Albert traduziu por "espelho" não se aplica aos nossos espelhos iconofóricos. Ao comentar uma versão anterior do presente artigo,

28. Ver o mito shipibo analisado por Roe (1988; 120; 1990 : 139-40 n. 12): os espíritos chaiconi (Incas-cunhados) “"viraram o espelho do outro lado' e assim obscureceram a habilidade humana primordial de ver os animais de caça e os peixes que procuravam fisgar nas águas cristalinas do lago da origem dos tempos. Agora que o espelho está virado com sua face cega para os humanos, eles não podem ver os animais que caçam... exceto se estes se acham perto da superfície... Como o xamã, por meio de suas visóes alucinatórias, pode voltar ao início dos tempos, ele será capaz de 'desvirar o espelho' e ver claramente. Dessa forma, os xamãs estão associados aos espelhos e os usam como ornamento...”. 
onde eu explorava a suposta propriedade dos espelhos yanomami de refletir imagens, Albert generosamente me comunicou a seguinte explicação adicional, e crucial, que Davi Kopenawa lhe deu em resposta às suas questóes sobre os espelhos xamânico-espirituais. A passagem abaixo reescreve o que se lê a certa altura de "Les ancêtres animaux":

Os xapiripë não se deslocam jamais sobre a terra. Eles a acham demasiado suja e cheia de excrementos. O solo sobre o qual dançam parece com vidro, e brilha de uma luz ofuscante. Ele é formado daquilo que nossos antigos chamam de mire kopë ou mire xipë. Estes são os objetos dos xapiripë, magníficos e rutilantes, transparentes mas muito sólidos. Vocês diriam "espelhos". Mas não são espelhos de se olhar, são espelhos que brilham ${ }^{29}$.

Luz, não imagens. Os xapiripë são de fato imagens (utupë), mas seus espelhos não os constituem como tal - estáo do lado da pura luz. Cristais.

\section{Tamanho e intensidade}

Além da luminosidade ofuscante, os xapiri$p \ddot{e}$, enquanto perceptos, mostram duas outras características, a pequenez e a inumerabilidade. No discurso acima transcrito, já vimos que "eles parecem seres humanos mas são tão minúsculos quanto partículas de poeira cintilantes [...] milhares deles chegam para dançar juntos... seus caminhos parecem teias de aranha... Os espí-

29. Nota de Bruce Albert (com. pess.): "De fato, os espelhos industriais são designados pelos Yanomami orientais pelo termo mirena (mire para os Yanomami ocidentais), que se distingue, ainda que formado a partir da mesma raiz (mire- = ?), do termo que denota os 'espelhos' dos espíritos, mirekopë ou mirexipë. Aliás, mirexipë designa igualmente os bancos de areia misturada de mica que brilham nas águas claras dos riachos das terras altas da região yanomami. E, por fim, $x i$ significa 'luz, radiância, emanação'”. ritos são assim tão numerosos porque eles são a imagem dos animais da floresta..." $\mathrm{Na}$ versão ampliada, naturalmente, o número de vezes em que eles são ditos "inumeráveis" é proporcionalmente maior. $\mathrm{O}$ narrador se compraz em enumerar esta proliferação inumerável:

Suas imagens são magníficas. Não pensem que só haja alguns deles. Os xapiripë são verdadeiramente muito numerosos. Eles não terminam nunca de vir até nós, sem número e sem fim. Eles são as imagens dos animais que habitam a floresta, com todos os seus filhotes, que descem uns atrás dos outros. Não são eles inumeráveis, todos os japus, as araras vermelhas e amarelas, os tucanos, os mutuns, os jacamins, os jacus, os periquitos, os falcóes, os morcegos, os urubus... E aí os jabutis, os tatus, os tapires, os veados, as jaguatiricas, os jaguares, as cutias, os queixadas e os macacos-aranha, os guaribas, os macacosprego, os cairaras, as preguiças... E ainda todos os peixes dos rios, os poraquês, as piranhas, os bagres kurito, as arraias e todos os peixinhos? (Kopenawa \& Albert 2003: 72).

Minúsculos, esses espíritos nem por isso deixam de manifestar uma intensa vitalidade (cf. os animais descendo com todos os seus filhotes) e uma superabundância de ser: "quando eu era mais moço, eu me perguntava se os xapiripë podiam morrer como os humanos. Mas hoje sei que, mesmo sendo minúsculos, eles são poderosos e imortais" (ibid: 81$)^{30}$. Os espíritos são, literalmente, intensos: o sufixo -ri que geralmente acompanha o nome dos xapiripe "denota a extrema intensidade ou a qualidade de não-humano/invisível" (Albert in ibid:

30. Essas idéias yanomami sobre a inumerabilidade e imortalidade dos espíritos animais talvez possam ser relacionadas o tema da regeneração infinita das espécies, objeto de uma importante discussão de R. Brightman em suas etnografia dos Cree do Canadá (1993: ch. 9). 
73 n.30). Eis porque por exemplo, os antepassados animais mitológicos e suas imagens xamânicas atuais são chamadas yaroripë, ou seja, yaro $($ caça $)+r i-($ excessivo, sobrenatural $)+p \ddot{e}$ (pluralizador). Intensidade, exemplaridade, alteridade em relação ao meramente existente:

[O] macaco guariba iro que flechamos nas árvores é outro que sua imagem, aquela que o xamá faz descer como Irori, o espírito-guariba. Essas imagens utupë da caça são verdadeiramente muito belas. [...] Comparadas a elas, os animais da floresta são feios. Eles existem, apenas. Eles não fazem senão imitar suas próprias imagens. Eles são apenas o alimento dos humanos. (ibid: 73).

O intensificador-espiritualizador -ri parece assim funcionar exatamente como o modificador -kumã nas línguas aruaque do Alto Xingu, que os Yawalapíti me traduziram por "gigantesco, feroz, outro, sobrenatural, estranho”, e que interpretei (Viveiros de Castro 2002a) como um dos operadores conceituais básicos de sua cultura, o operador de alteraçáo-espiritualização ou "exponenciação ontológica". Interessantemente, a imagística dimensional dos seres-kumã faz deles versóes maiores, por vezes gigantescas e monstruosas, dos seres mundanos: um macaco-kumã yawalapíti não é minúsculo como o Irori yanomami. Mas estamos diante, penso, do mesmo macaco, ou antes, do mesmo outro do macaco, nos Yawalapíti como nos Yanomami. A minuscularidade dos espíritos xapiripë não é obstáculo a sua natureza "excessiva" ou "extremamente intensa", como diz Albert: pelo contrário, parece-me que ela é um signo decisivo da multiplicidade designada pelo conceito de qualquer espírito "em particular": "[Q] uando se diz o nome de um xapiripë, náo é um só espírito que se evoca, é uma multidão de espíritos semelhantes" (ibid: 73). Os espíritos são quantitativamente múltiplos, infinitamente numerosos; eles formam a estrutura molecular última das formas animais molares que vemos na floresta. Sua pequenez é função de sua infinitude e não o contrário. Da mesma forma, o caráter geralmente gigantesco dos seres-kumã dos Yawalapíti não os faz menos invisíveis aos olhos desarmados - e esse caráter os determina como qualitativamente múltiplos, visto que um ser-kumã é ao mesmo tempo o arquétipo e um monstro, um modelo e seu excesso, a forma pura e uma reverberação híbrida (entre humano e animal, por exemplo), a beleza e a ferocidade em uma só figura. Assim, a minuscularidade e numerosidade dos xapiripë marca sua natureza de bando, enxame, matilha e multidáo, enquanto o gigantismo dos seres-kumã aponta para a figura do "anomal", o representante excepcional da espécie, o megaindivíduo que indica a fronteira de uma multiplicidade animal (Deleuze \& Guattari 1980) ${ }^{31}$. Em suma, a pequenez dos xapiripë e a natureza frequentemente agigantada dos espíritos de outras culturas (os Mestres dos Animais, por exemplo) são como a frente e o verso de uma mesma idéia, os dois esquematismos extensivos complementares da multiplicidade intensiva e da intensidade "excessiva" dos espíritos ${ }^{32}$.

31. A determinação conceitual dos espíritos como multiplicidades possui implicaçôes sociológicas fascinantes, que não posso elaborar aqui. Contento-me em citar o que diz P. Gow (2001: 148) sobre a natureza essencialmente coletiva das interaçôes com os espíritos: "Quando um xamã canta a canção de um kayigawlu [a visão xamânica de um "ser poderoso" i.e. um espírito] ele se torna este kayigawlu. Mas... a condicáo dos seres poderosos é essencialmente múltipla... [A] imitaçẫo das cançôes dos seres poderosos é menos uma forma de possessão que o ingresso em uma outra socialidade. [...] O Outro incorpora o xamã como parte de sua multiplicidade...".

32. A oscilação complexa entre as idéias de minuscularidade e de monstruosidade como esquematismos alternativos de uma multiplicidade intensiva foi muito bem caracterizada por Rodgers a propósito dos Ikpeng: "O potencial de expandir os pontos mínimos e obscuros do mundo é um traço distintivo do pensamento cosmológico ikpeng - seres pequenos (tikap) como os 
À guisa de conclusão, gostaria apenas de observar que o problema do infinito nas cosmologias ameríndias parece-me estar em aberto. Acostumamo-nos a contrastar o "mundo fechado" dos assim chamados primitivos ao "universo infinito" dos assim chamados modernos, e a atribuir aos primeiros, representados aqui pelos povos nativos das Américas, uma filosofia fundamentalmente finitista, combinatória e discretizante; uma filosofia que aborreceria o contínuo como se visse nele o terrível labirinto que conduz ao império do não-senso. Refiro-me aqui, o leitor terá compreendido, ao logos chamado "estruturalista", ou melhor, à vulgata homônima que nos instruiu a conceber todo movimento de diferenciação como pura síntese limitativa de especiação e a entender o real como simples manifestação combinatória do possível. Mas os espelhos cristalinos e moleculares, as imagens inumeráveis e os espíritos minusculamente incontáveis das narrativas de Davi Kopenawa sugerem fortemente que a dimensão propriamente infinitesimal, intensiva, disjuntiva e virtual do pensamento ameríndio ainda aguarda maior atenção por parte da antropologia.

\section{The crystal forest: on the ontology of Amazonian spirits}

abstract This article is a reflection on the ontology of spirits in the indigenous Amazon region. A narrative by David Kopenawa (yanomami thinker and political leader) about the xapiripë (animal ancestors or shamanic spirits that interact with their shamans) is the central inspiration for a broad-

colibris, os esquilos, as abelhas e vários peixinhos são os seres mais potentes: são todos xamânicos, piat-pe" (2002: 100). E eis aqui algo que minha colega Tânia Stolze Lima encontrou em algum trecho da etnografia de Lizot sobre as ariranhas, de acordo com um mito yanomami: "As ariranhas levantam suas cabeças [emergindo da superfície da água] porque elas percebem os Yanomami como pontos minúsculos”. Molecularidade e perspectivismo em uma única fórmula! er discussion on the cosmology and shamanism in the Amazon region. In this discussion the amazonic concept of "spirits" do not define a specific class or type of being, but rather a disjunctive synthesis between the human and the non-human. The theme of the characteristic intense light associated with spirits is interpreted as a non-representative emphasis in the view of the perception and knowledge model in indigenous cultures in the American continent. Kopenawa states that the Yanomami shamans know that their forest belongs to xapiripe and it is formed by "mirrors", that is, bright crystals. Therefore the crystal forest does not reflect or produces images, but rather glares, shines and radiates.

keywords Yanomami. Ontology. Spirits. Cosmology. Shamanism. Light.

\section{Referências bibliográficas}

ALBERT, B. 1998. La fumée du métal: histoire et représentations du contact chez les Yanomami (Brésil). L'Homme, 106-107XXVIII: 87-119.

1993. L'Or cannibale et la chute du ciel: une critique chamanique de l'économie politique de la nature. L'Homme, 126-128 XXXIII: 349-378.

ALBERT, B.; H. CHANDÈS (Orgs.). 2003. Yanomami: l'esprit de la forêt. Paris: Fondation Cartier / Actes Sud.

ALEXIADES, M. 1999. Ethnobotany of the Ese Eja: plants, health, and change in an Amazonian society. Ph.D., University of New Cork.

2000. El eyámikekwa y el ayahuasquero: las dinámicas socioecológicas del chamanismo ese eja. Amazonia Peruana, 27: 193-212.

BORGES, J. L. Tlön, Uqbar, Orbis Tertius. In: Ficciones. Buenos Aires: Emecé, 1956.

BRIGHTMAN, R. A. 1993. Grateful prey: Rock Cree human-animal relationships. Berkeley / Los Angeles / Oxford: University of California Press.

CAMPBELL, A.T. 1989. To square with genesis: causal statements and shamanic ideas in Wayäpí. Edinburgo: Edinburgh University Press.

CARNEIRO DA CUNHA, M.M. 1998. "Pontos de vista sobre a floresta amazônica: xamanismo e tradução”. Mana, 4(1): 7-22.

CHAUMEIL, J.-P. 1983. Voir, savoir, pouvoir: le chamanisme chez les Yagua du Nord-Est péruvien. Paris: Ecole des Hautes Etudes en Sciences Sociales. 
CLASTRES, P. 1968. "Ethnographie des indiens Guayaki (Paraguay-Brésil)". Journal de la Société des Américanistes, LVII: 8-61.

DELEUZE, G. 1993. Critique et clinique. Paris: Minuit.

DELEUZE, G. ; F. GUATTARI. 1980. Milles plateaux. Paris: Minuit.

JARA, F. 1996. El camino del kumu: ecología y ritual entre los Akuriyó de Surinam. Quito: Abya-Yala.

GALLOIS, D. 1984-85. "O pajé wayápi e seus espelhos". Revista de Antropologia, 27-28: 179-196.

1996. "Xamanismo waiāpi: nos caminhos invisíveis, a relaçāo i-paie”. In E.J.M. Langdon (ed.), Xamanismo no Brasil: novas perspectivas. Florianópolis: Editora da UFSC.

GELL, A. 1998. Art and agency: an anthropological theory. Oxford: Clarendon.

GONÇALVES, M.A.T. 2001. O mundo inacabado: ação e criação em uma cosmologia amazônica. Rio de Janeiro: Editora da UFRJ.

GOW, P. 1999. "Piro designs: painting as meaningful action in an Amazonian lived world". Journal of the Royal Anthropological Institute, 5: 229-246.

2001. An Amazonian myth and its history. Oxford: Oxford University Press.

GRAY, A. 1996. The Arakmbut of Amazonian Peru, 1: mythology, spirituality, and history in an Amazonian community. Providence / Oxford: Berghahn Books.

GUSS, D. 1989. To weave and to sing: art, symbol, and narrative in the South American rain forest. Berkeley: University of California Press.

HUGH-JONES, S. 1996a. "Shamans, prophets, priests and pastors". In N. Thomas \& C. Humphrey (eds), Shamanism, history, and the state. Ann Arbor: University of Michigan Press.

1996b. "Bonnes raisons ou mauvaise conscience? De l'ambivalence de certains Amazoniens envers la consommation de viande". Terrain, 26: 123-48.

HURAULT, J. 1968. Les Indiens Wayana de la Guiane Française. Paris: ORSTOM.

INGOLD, T. 2000. The perception of the environment. Essays on livelihood, dwelling and skill. London: Routledge.

KELLY, J.A. 2003. Relations within the health system among the Yanomami of the Upper Orinoco, Venezuela. Ph.D. thesis. Cambridge University.

KENSINGER, K. 1995. How real people ought to live: the Cashinahua of Eastern Peru. Prospect Hights: Waveland Press.

KOPENAWA, D.Y. 2000. "Sonhos das origens". In C.A. Ricardo (ed), Povos indígenas no Brasil (1996-2000). São Paulo: ISA.
KOPENAWA, D.Y. 2004. "Xapiripë”. In B. Albert \& D. Kopenawa, Yanomami, o espirito da floresta. Rio de Janeiro: Centro Cultural Banco do Brasil / Fondation Cartier.

KOPENAWA, D.Y. ; B. ALBERT. 2003. "Les ancêtres animaux". In B. Albert e H. Chandès. (eds.), Yanomami l'esprit de la forêt. Paris: Fondation Cartier / Actes Sud.

KRACKE, W. 1987. "Everyone who dreams has a bit of shaman': cultural and personal meaning of dreams evidence from the Amazon". Psychiatric Journal of the University of Ottawa, 12: 65-72.

LAGROU, E.M. 1998. Cashinahua cosmovision: a perspectival approach to identity and alterity. Ph.D. thesis. University of St. Andrews.

LÉVI-STRAUSS, C. 1964. Mythologiques I: Le cru et le cuit. Paris: Plon.

1971. Mythologiques IV: L'Homme nu. Paris: Plon.

LÉVI-STRAUSS, C. ; D. ERIBON. 1988. De près et de loin. Paris: Odile Jacob.

LIENHARDT, Godfrey. 1961. Divinity and experience: the religion of the Dinka. Oxford: Claredon Press.

MENTORE, G. 1993. "Tempering the social self: body adornment, vital substance, and knowledge among the Waiwai”. Journal of Archaeology and Anthropology, (9): 22-34.

MONOD, J. 1987. Wora, la déesse cachée. Paris: Les Editeurs Evidant.

OVERING, J. 1985. "Today I shall call him 'mummy': multiple worlds and classificatory confusion". In J. Overing (ed.), Reason and morality. ASA Monographs 24. London: Tavistock.

POLLOCK, D. 1985. Personhood and illness among the Culina of Western Brazil. Ph.D. thesis. University of Rochester.

REICHEL-DOLMATOFF, G. 1975. The shaman and the jaguar: a study of narcotic drugs among the Indians of $\mathrm{Co}^{-}$ lombia. Philadelphia: Temple University Press.

.1978. "Drug-induced optical sensations and their relationship to applied art among some Colmbian Indians". In M. Greenhalgh \& V. Megaw (ed.), Art in society: studies in style, culture and aesthetics. New York: St Martin's Press.

RODGERS. D. 2002. "A soma anômala: a questáo do suplemento no xamanismo e menstruaçăo ikpeng". Mana, 8(2): 91-125.

ROE, P.G. 1982. The cosmic zygote: cosmology in the Amazon Basin. New Brunswick: Rutgers University Press.

.1988. "The Josho Nahuanbo are all wet and undercooked: Shipibo views of the Whiteman and the Incas in myth, legend, and history". In J.D. Hill (ed.), Rethinking 
history and myth: indigenous South American perspectives on the past. Urbana \& Chicago: University of Illinois Press.

.1990. "Impossible marriages: animal seduction tales among the Shipibo Indians of the Peruvian jungle". Journal of Latin American Lore, 16: 131-173.

SCHREMPP, G. 1992. Magical Arrows: The Maori, the Greeks, and the Folklore of the Universe. Madison: University of Wisconsin Press.

SCHWARTZMAN, S. 1988. The Panara of the Xingu National Park. Ph.D. thesis, The University of Chicago.

SIMONDON, G. 1995. Lindividu et sa génèse physico-biologique. Paris: Millon.

SMITH, D. 1998. "An Athapaskan way of knowing: Chipewyan ontology". American Ethnologist, 25: 412-432.

STORRIE, R. 2003. "Equivalence, personhood and relationality: processes of relatedness among the Hoti of Venezuelan Guiana”. Journal of the Royal Anthropological Institute, 9: 407-428.

STRATHERN, M. 1991. Partial connections. Savage, MD: Rowman \& Littlefield Publishers.

TAUSSIG, M. 1987. Shamanism, colonialism, and the White Man. Chicago: University of Chicago Press.

TAYLOR, A.-C. 1993. "Remembering to forget: identity, mourning and memory among the Jívaro". Man, 28: 653-678.

TOWNSLEY, G. 1993. "Song paths: the ways and means of Yaminahua shamanic knowledge". L'Homme, 126-128 XXXIII: 449-468.

TURNER, T. 1995. "Social body and embodied subject: bodiliness, subjectivity, and sociality among the Kayapo". Cultural Anthropology, 10: 143-170.

URBAN, G. 1996. Metaphysical community: the interplay of the senses and the intellect. Austin: University of Texas Press.

VALERI , Valerio. 2000. The forest of taboos: morality, hunting, and identity among the Huaulu of the Moluccas. Madison: University of Wisconsin Press.

van VELTHEM, L.H. 2003. O belo é a fera: a estética da produção e da predação entre os Wayana. Lisboa: Assírio $\&$ Alvim.
VILAÇA, A. 1992. Comendo como gente: formas do canibalismo wari. Rio de Janeiro: Editora da UFRJ.

VIVEIROS DE CASTRO, E.B. 1992. From the enemy's point of view: humanity and divinity in an Amazonian society. (trans.) C. Howard. Chicago: University of Chicago Press. .1998. "Cosmological deixis and Ameridian perspectivism". Journal of the Royal Anthropological Institute, 4: 469-488.

2001. "GUT feelings about Amazonia: potential affinity and the construction of sociality". In L. Rival \& $\mathrm{N}$. Whitehead (eds.)Beyond the visible and the material: the amerindianization of society in the work of Peter Rivière. Oxford: Oxford University Press.

.2002a [1978]. "Esboço de cosmologia yawalapíti". In __. A inconstância da alma selvagem. São Paulo: Cosac \& Naify.

.2002b. "Xamanismo e sacrifício". In A inconstância da alma selvagem. São Paulo: Cosac \& Naify. WEISS, G. 1972. "Campa cosmology”. Ethnology, XI: 157172.

\section{Agradecimentos}

Quero agradecer meu colega Bruce Albert por sua generosidade em permitir que eu citasse, parafraseasse e desavergonhadamente canibalizasse suas magníficas traduçóes e comentários das narrativas de Davi Kopenawa. $\mathrm{O}$ trabalho etnográfico de Albert sobre e com os Yanomami, por sua riqueza, precisão e profundidade excepcionais, representa um momento particularmente brilhante da antropologia amazônica. Agradeço por fim, e sobretudo, a Davi Kopenawa, pensador que qualquer civilização do planeta se orgulharia de poder contar entre os seus.

\section{autor Eduardo Viveiros de Castro}

Professor de Antropologia / MN-UFRJ

Recebido em 04/07/2006

Aceito para publicação em 08/10/2006 